\title{
PENGARUH PEMBERIAN EKSTRAK JAHE MERAH TERHADAP KARKAS DAN LEMAK ABDOMINAL PADA AYAM BROILER BETINA
}

\author{
Gatot Adiwinarto 1 \\ 1) Jurusan Penyuluhan Peternakan, STPP Magelang \\ Jl. Magelang-Kopeng Km 7 Purwosari, Tegalrejo, Magelang \\ E-mail: gatotleo@yahoo.co.id
}

Diterima: 22 Agustus 2016

Disetujui: 08 November 2016

\begin{abstract}
ABSTRAK
Penelitian ini bertujuan untuk mengetahui pengaruh pemberian ekstrak jahe merah pada ayam broiler betina terhadap berat karkas, persentase karkas, berat lemak abdominal dan persentase lemak abdominal. Bahan yang digunakan adalah ayam broiler betina umur 43 hari sebanyak 16 ekor. Rancangan penelitian menggunakan rancangan acak lengkap, perlakuan adalah pemberian ekstrak jahe merah dengan empat perlakuan, dan empat ulangan yaitu P0 tidak diberikan ekstrak jahe sebagai control, P1 diberikan dengan konsentrasi 5\%, P2 (10\%), dan P3 (15\%). Analisis data menggunakan sidik ragam. Hasil penelitian menunjukkan bahwa penambahan ekstrak jahe merah tidak menunjukkan hasil yang berbeda nyata terhadap berat karkas dan persentase karkas. Tetapi menunjukkan hasil yang berbeda nyata $(\mathrm{P}<0,05)$ terhadap berat lemak abdominal dan persentase lemak abdominal. Dari penelitian ini diperoleh kesimpulan bahwa pemberian ekstrak jahe merah dapat menurunkan berat dan presentase lemak abdominal, tetapi tidak mempengaruhi berat dan persentase karkas
\end{abstract}

Kata Kunci : Ayam broiler, Ekstrak Jahe, Karkas, Lemak Abdominal.

\section{EFFECT OF RED GINGER EXTRACT ON CARCASS AND ABDOMINAL FAT IN FEMALE BROILER CHICKENS}

\begin{abstract}
This study aimed to determine the effect of the red ginger extract on carcass weight, carcass percentage, abdominal fat weight, and abdominal fat percentage. Sixteen broiler females aged 43 days are used in this study. The study design used a completely randomized design, treatment is giving red ginger extract with four treatments and four replications ie $P 0$, is not given ginger extract as control, $P 1$ is given by the concentration of 5\%, P2 (10\%) and P3 (15\%). Analysis of the data using analysis of variance. The results showed that the addition of red ginger extract did not show significantly different results on carcass weight and carcass percentage. But showed a significantly $(P<0.05)$ abdominal fat weight and abdominal fat percentage. From this study we concluded that the red ginger extract can reduce weight and abdominal fat percentage, but does not affect the weight and carcass percentage
\end{abstract}

Keywords: Broiler chicken, ginger extract, carcass, abdominal fat 


\section{PENDAHULUAN}

Peternakan ayam broiler di Indonesia berkembang pesat dalam beberapa dekade terakhir. Konsumsi masyarakat terhadap produk hasil ternak dua puluh tahun lalu masih dipenuhi dari daging sapi, namun sekarang daging ayam juga dapat memenuhi kebutuhan masyarakat. Hal ini karena peternakan ayam broiler dikelola secara intensif sehingga produk daging cepat meningkat dan dapat menjangkau kebutuhan masyarakat.

Permintaan peningkatan kualitas produk daging ayam broiler sangat bervariasi, mulai dari rendahnya kandungan residu berbahaya, cita rasa yang enak, rasa seperti ayam kampung, serta kandungan lemak yang rendah. Peningkatan kualitas dapat dilakukan dengan berbagai cara, misal saat masih dalam pemeliharaan atau penanganan pasca panen. Untuk penanganan pada waktu pemeliharaan dapat melalui manajemen pemberian pakan dan minum, atau penambahan bahan-bahan alami yang diduga dapat meningkatkan kualitas daging.

Beberapa tahun terakhir penelitian tentang penggunaan bahan alami untuk peningkatan produktifitas sudah banyak dilakukan. Bahan serta variable yang diamati juga bervariasi. Sedangkan bahan yang banyak digunakan adalah tanaman obat dan bahan rempah.

Bahan yang dapat meningkatkan produktifitas salah satunya adalah rimpang jahe. Penelitian yang sudah dilakukan menyimpulkan bahwa penambahan tepung jahe emprit pada pakan mampu menurunkan lemak abdominal, meningkatkan kualitas karkas, serta menghasilkan daging yang lebih baik dari segi warna, tekstur, dan aroma (Sunaryo, 2004).
Tujuan yang ingin dicapai dalam pelaksanaan penelitian adalah mengetahui sejauh mana pengaruh pemberian ekstrak jahe merah terhadap berat karkas, persentase karkas, berat lemak abdominal, dan persentase lemak abdominal pada ayam broiler betina umur 43 hari.

\section{MATERI DAN METODE \\ Lokasi penelitian}

Penelitian ini dilaksanakan di Laboratorium Ternak Unggas dan Aneka Ternak Sekolah Tinggi Penyuluhan Pertanian Magelang.

\section{Materi}

Alat- alat yang digunakan pada saat pengambilan data penelitian adalah a). pisau, b) nampan, c) gunting, d) pinset, e) timbangan elektrik, f) ember, g) gayung, h) keranjang. Bahan yang digunakan dalam penelitian adalah a) Ayam broiler betina umur 43 hari sebanyak 16 ekor, b) plastik, c) pewarna untuk memberikan tanda pada ayam yang dipotong.

Cara pembuatan ekstrak jahe merah adalah sebagai berikut bersihkan jahe merah dari kotoran yang menempel hingga bersih dengan air. Setelah jahe dicuci kemudian ditiriskan sampai kering, rimpang jahe kemudian diiris kecil-kecil. Irisan jahe merah tersebut dimasukkan dalam panci dan air sebanyak 6 liter air dan jahe $1 \mathrm{~kg}$, rebus sampai separuhnya (3 liter), angkat panci yang berisi rebusan jahe merah, dan didinginkan. Setelah dingin diisi dalam botol yang sudah disterilkan atau ditempat yang aman dan siap digunakan. Pembuatan ekstrak jahe dilakukan dua hari sekali.

\section{Metode}

Penelitian ini dilaksanakan dengan menggunakan metode eksperiment desain (Supranto J. 2003) yaitu dengan 
membandingkan antara ayam broiler yang diberikan ekstrak jahe merah dengan yang tidak diberikan ekstrak jahe merah. Metode pelaksanaanya dengan membandingkan antara ayam yang diberikan ekstrak jahe merah dengan konsentrasi 0\%, 5\%, 10\%, dan $15 \%$.

Faktor yang diukur adalah pemberian ekstrak jahe merah dengan empat perlakuan empat ulangan yaitu P0 tidak diberikan ekstrak jahe sebagai control, P1 diberikan dengan konsentrasi 5\%, P2 10\%, dan P3 $15 \%$.Sampel ayam yang diambil sebanyak
32 ekor di bagi menjadi empat perlakuan dan empat ulangan dan ditempatkan dalam kandang unit. Setiap kandang unit diisi dua ekor ayam betina. Jumlah kandang yang diperlukan dalam penelitian sebanyak 16 unit kandang. Ukuran kandangnya yaitu panjang $80 \mathrm{~cm}$ x lebar $60 \mathrm{~cm}$ dan tinggi 60 $\mathrm{cm}$. Kadang penelitian ini ditempatkan menjadi dua baris dengan arah kandang yang saling berhadap-hadapan, setiap barisnya terdiri dari delapan unit kandang penelitian.

\begin{tabular}{|l|c|c|c|c|c|c|c|}
\hline P1.4 & P0. 1 & P3. 2 & P2. 1 & P3. 1 & P1.2 & P0.3 & P2. 2 \\
\hline 1 & 2 & 3 & 4 & 5 & 6 & 7 & 8 \\
\hline
\end{tabular}

\begin{tabular}{|c|c|c|c|c|c|c|c|}
\hline 9 & 10 & 11 & 12 & 13 & 14 & 15 & 16 \\
\hline P3.3 & P2.3 & P0.4 & P1.3 & P0.2 & P2.4 & P3.4 & P1. 1 \\
\hline
\end{tabular}

\section{Gambar 1. Posisi Kandang Penelitian}

Pada penelitian pakan yang digunakan ada dua macam yaitu pakan dari pabrik dan pakan pencampuran sendiri. Pakan dari pabrik diberikan pada umur 1 hari sampai dengan umur 15 hari, sedangkan pakan pencampuran sendiri diberikan pada waktu penelitian yaitu umur 15 hari sampai dengan 42 hari. Bahan yang digunakan untuk pakan pencampuran sendiri adalah jagung 50\%, konsentrat pabrik $40 \%$, bekatul $10 \%$ dan diperoleh kandungan protein $19-21 \%$.

Pakan dan air minum diberikan secara Adlibitum, sedangkan pemberian ekstrak jahe merah diberikan pada malam hari. Konsentrasi yang diberikan sesuai dengan rancangan yaitu $0 \%$ sebagai kontrol, 5\%, $10 \%$, dan $15 \%$. Untuk mengetahui konsumsi pakan dilakukan penimbangan setiap minggu.

Program pencegahan penyakit yang dilakukan yaitu dengan sanitasi dan vaksinasi. Untuk sanitasi kegiatan yang dilakukan adalah dengan penyemprotan kandang, pencucian peralatan dengan desinfektan dan biosekuriti. Penyemprotan dilakukan dua kali seminggu, sedangkan perlakuan untuk biosecuriti petugas disemprot dengan desinfektan sebelum melakukan pekerjaan. Sedangkan vaksinasi dilakukan sebanyak tiga kali. Vaksin yang diberikan yaitu ND IB, ND Lasota dan gumboro. Untuk mencegah stres setelah di vaksin, diberikan vitamin sebelum dan sesudah dilakukan vaksin, sehingga kondisi ayam tetap baik.

Mengetahui karkas dan lemak abdominal dilakukan pemotongan sebanyak 16 ekor ayam betina pada umur 43 hari. Data yang diambil adalah berat karkas, berat non karkas, berat lemak abdominal, berat potong sebelum dipuasakan dan sesudah dipuasakan. Pemotongan dilakukan pada umur 43 hari dan pengambilan data diselesaikan pada hari tersebut. 
Jumlah ayam broiler betina yang dipotong adalah 16 ekor, diambil satu ekor dari masing-masing unit. Ayam dipuasaan terlebih dahulu sebelum dilakukan pemotongan, hal ini bertujuan untuk mendapatkan berat potong bersih tanpa kotoran di dalam saluran pencernaan. Pemuasaan dilakukan selama 5 sampai dengan 10 jam. Sebelum dipuasaan terlebih dahulu ditimbang untuk mengetahui bobot sebelum puasa dan dilakukan penimbangan kembali sebelum pemotongan untuk memperoleh bobot setelah puasa.

Setelah ditimbang dan diketahui bobot setelah puasa kemudian dilakukan pemotongan. Pemotongan dilakukan dengan cara memutus urat pada bagian leher, yang meliputi pembuluh darah vena, saluran pernapasan, dan saluran pencernaan (kerongkongan), setelah itu kemudian dilakukan pencabutan bulu. Pencabutan bulu dengan cara kering. Dari hasil pemotongan ini bagian-bagian yang diambil dan ditimbang adalah karkas dan non karkas. Untuk bagian non karkas antara lain darah, bulu, jeroan, kaki, kepala, dan leher.

Untuk memperoleh berat lemak abdominal yaitu dengan cara membedah pada bagian perut kemudian mengambil timbunan lemak disekitar rongga abdomen dan ampela, setelah itu dilakukan penimbangan.

\section{Variabel Penelitian}

Variabel yang diamati adalah persentase karkas dan lemak abdominal ayam broiler betina umur 43 hari.

\section{Karkas ayam.}

Diperoleh dengan cara menyembelih kemudian mengurangi darah, bulu, alat-alat tubuh bagian dalam (jeroan), kepala, leher, dan kakinya, kemudian ditimbang. Untuk mengetahui persentase karkas dilakukan perhitungan menggunakan rumus:

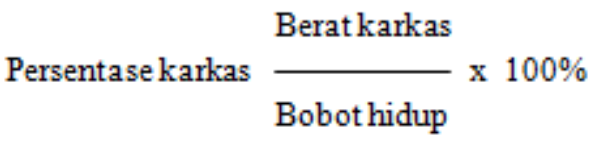

\section{Lemak abdominal ayam broiler.}

Untuk mengetahui berat lemak abdominal dilakukan pembedahan, kemudian dikeluarkan bagian jeroan beserta ampelanya, dan diambil lemaknya kemudian ditimbang. Untuk mengetahui persentase Lemak abdominal dapat diperoleh dengan rumus:

Persentase lemak abdominal $=\frac{\text { Berat lemak abdominal }}{\text { Bobothidup }} \times 100 \%$

\section{Analisis data}

Analisis data menggunakan sidik ragam dan apabila ada perbedaan rata-rata yang nyata dilanjutkan dengan uji Duncan.

\section{HASIL DAN PEMBAHASAN \\ Karkas Ayam Broiler Betina}

Hasil rata - rata bobot hidup, berat karkas dan persentase karkas ayam broiler betina umur 43 hari dapat dilihat pada Tabel 1. 
Tabel 1. Pengaruh Ekstrak Jahe Merah Terhadap Berat Karkas dan Persentase Karkas Ayam Broiler Betina Umur 43 Hari

\begin{tabular}{llll}
\hline \hline Perlakuan & $\begin{array}{l}\text { Bobot hidup } \\
\text { (gram) }\end{array}$ & Berat karkas (gram) & $\begin{array}{l}\text { Persentase karkas } \\
(\boldsymbol{\%})\end{array}$ \\
\hline P0 & 2050,15 & 1400,70 & 68,48 \\
P1 & 2109,03 & 1411,33 & 67,15 \\
P2 & 2200,15 & 1458,30 & 66,39 \\
P3 & 2174,78 & 1513,50 & 69,60 \\
\hline ns
\end{tabular}

${ }^{\mathrm{ns}}$ non signifikan

\section{Berat karkas}

Hasil perhitungan menunjukan tidak terjadi perbedaan yang nyata terhadap berat karkas. Pemberian ekstrak jahe merah secara statistik tidak berbeda antara control dengan perlakuan, tetapi secara rata-rata menunjukkan adanya perubahan. Jika dilihat rata-rata berat karkas tertinggi adalah pada P3 $(1400,70)$ kemudian P2 (1458,30), P1 (1411,33), dan P0 (1400,70). Bobot karkas terendah adalah PO. Walaupun perhitungan statistik tidak terdapat perbedaan yang nyata namun dilihat dari rata - rata berat karkas antara $\mathrm{P} 0=1400,70$ gram dengan $\mathrm{P} 3=1513,50$ gram, terdapat selisih sebesar 112,80 gram.

Berat karkas yang dihasilkan dari keempat perlakuan masih tergolong baik dimana berat karkas tersebut sesuai dengan Adiwinarto (2004) bahwa rata - rata karkas hasil pemotongan ayam broiler umur 42 hari adalah sebesar 1226,23 gram.

Faktor yang mempengaruhi berat karkas ini dimungkinkan oleh genetik seperti galur dan jenis kelamin. Hal ini sesuai dengan pendapat Soeparno (1999) bahwa kualitas karkas dan daging dipengaruhi oleh faktor sebelum dan setelah pemotongan. Faktor sebelum pemotongan antara lain genetik, spesies, bangsa, tipe ternak, jenis kelamin, umur, pakan termasuk bahan additive (hormon, antibiotik atau mineral), dan stress.
Jahe mengandung minyak atsiri dan kurkumin berperan meningkatkan kerja organ pencernaan, merangsang getah pankreas yang mengandung enzim amilase, lipase, dan protease, akan tetapi jika penggunaan jahe berlebihan maka akan menyebabkan dampak negatif (toksik) pada tubuh ayam (Herawati, 2006). Andoko dan Hartomo (2005), manfaat jahe secara farmakologi antara lain sebagai anti pengeresan pembuluh darah, anti parasit, dan merangsang pengeluran getah lambung dan getah empedu.

\section{Persentase karkas}

Hasil perhitungan statistik menunjukan bahwa pemberian ekstrak jahe merah tidak memberikan perbedaan terhadap persentase karkas. Tetapi apabila dilihat dari rata - rata persentase, P3 (69.60\%) merupakan persentase karkas tertinggi, kemudian P0 $(68,48 \%), \quad$ P1 $(67,15 \%)$, dan persentase terendah pada P2 $(66,39 \%)$. Pemberian ekstrak jahe pada level 5\% (P1) dan 10\% (P2) secara rata-rata lebih rendah dibandingkan control, dan dilihat dari rata-rata pemberian ekstrak jahe pada level $15 \%$ (P3) walaupun tidak terdapat perbedaan nyata tetapi cenderung memperlihatkan persentase karkas tertinggi

Persentase karkas dilihat secara ratarata dapat dikategorikan baik walaupun pemberian ekstrak jahe merah tidak berbeda, karkas yang dihasilkan masih 
mampu dipertahankan. Seperti yang dikemukakan Sudrajad (1998) dimana persentase berat karkas ayam broiler antara $65 \%$ hingga $70 \%$ dari bobot hidup. Pemberian jamu atau tanaman obat yang dicampurkan baik dalam pakan maupun air minum ayam dapat bermanfaat meningkatkan berat badan ayam dan menambah nafsu makan sehingga dapat berdampak meningkatnya persentase berat karkas (Zumrotun, 2012). Kualitas karkas yang dihasilkan termasuk dalam mutu I.
Berdasarkan pendapat yang dinyatakan oleh Abubakar (2003) bahwa mutu persentase karkas dibagi menjadi tiga kelas, yaitu mutu I dengan persentase antara $51,75 \%$ sampai $66,55 \%$, mutu II $27,97 \%$ sampai $43,03 \%$, dan mutu III yaitu antara 5,13 sampai $18,17 \%$.

\section{Lemak Abdominal}

Rata - rata berat dan persentase lemak abdominal ayam broiler betina umur 43 hari dapat dilihat pada Tabel 2.

Tabel 2. Pengaruh Ekstrak Jahe Merah Terhadap Berat dan Persentase Lemak Abdominal Ayam Broiler Betina Umur 43 Hari.

\begin{tabular}{lll}
\hline \hline Perlakuan & Berat Lmk abdominal (gram) & Persentase Lmk abdominal $(\%)$ \\
\hline T0 & $42,98^{\mathrm{b}}$ & $3,06^{\mathrm{b}}$ \\
T1 & $23,50^{\mathrm{a}}$ & $1,64^{\mathrm{a}}$ \\
T2 & $26,85^{\mathrm{a}}$ & $1,84^{\mathrm{a}}$ \\
T3 & $21,58^{\mathrm{a}}$ & $1,58^{\mathrm{a}}$ \\
\hline
\end{tabular}

${ }^{\mathrm{a}, \mathrm{b}}$ Superskrip pada kolom yang sama menunjukkan perbedaan yang nyata $(\mathrm{P}<0,05)$

\section{Berat lemak abdominal}

Perhitungan statistik menunjukkan bahwa pemberian ekstrak jahe merah memberikan pengaruh yang nyata $(\mathrm{P}<0.05)$ terhadap berat lemak abdominal. Pemberian pada level 5\% (P1) berat lemak abdominal 23,50 gram, kemudian pemberian pada level $10 \%$ (P2) berat 26,85 gram, pada level $15 \%$ (P3) berat 21,58 gram, dan pada kontrol (P0) berat lemak abdominal 42,98 gram. Dari rata - rata tersebut berat tertinggi pada P0 dan berat terendah pada P3. Dari hasil tersebut terdapat perbedaan yang signifikan antara P0 sebagai kontrol dengan P1, P2, dan P3, akan tetapi tidak terdapat perbedaan yang signifikan antara P1, P2, dan P3.

Penurunan berat lemak abdominal tersebut dikarenakan jahe merah dapat memperbaiki dan meningkatkan metabolisme pencernaan lemak, seperti pendapat Koswara (2007) dan Health, (2007), dimana jahe merah yang diberikan pada ayam broiler akan meningkatkan enzim protease dan lipase sehingga dapat meningkatkan metabolisme dalam tubuh. Jahe merah bermanfaat menurunkan lemak abdominal juga dinyatakan oleh Herawati (2007) dimana penambahan fitobiotik jahe merah 0,5-2\% pada pakan memberikan bobot lemak abdominal yang lebih rendah. Proses yang terjadi adalah senyawa aktif gingerol dari jahe merah yang memberikan rasa pedas diduga sebagai penyebab meningkatnya aktifitas ayam broiler. Akibat dari aktifitas yang meningkat ayam broiler membutuhkan energi yang lebih besar. Energi tersebut didapat dari hasil metabolisme glukosa oleh sel hati. Apabila glukosa darah habis maka ayam akan membongkar cadangan glikogen dalam hati, namun jika jumlah glikogen belum juga mencukupi maka lemak yang ditimbun akan dibongkar untuk memenuhi kekurangan energi tersebut. Akibat dibongkarnya lemak sebagai sumber energi, 
maka lemak yang ditimbun di dalam tubuh semakin berkurang.

\section{Persentase lemak abdominal}

Perhitungan statistik menunjukan bahwa pemberian ekstrak jahe merah memberikan pengaruh yang nyata $(\mathrm{P}<0.05)$ terhadap persentase lemak abdominal. Perbedaan yang signifikan yaitu antara pelakuan dengan control. P0 (Kontrol) persentase lemak abdominalnya mencapai $3,06 \%$, sedangkan pada P1 $(1,64 \%)$, P2 $(1,84 \%)$, dan P3 (1,58\%). Persentase lemak terendah adalah pada level pemberian $15 \%$ (P3) dan persentase tertinggi pada P0.

Penurunan persentase lemak abdominal ternyata dipengaruhi dari berat lemak, dimana perhitunganya diperoleh dengan cara berat lemak dibagi dengan bobot hidup kemudian dikalikan $100 \%$. Sehingga dari hasil perhitungan tersebut ternyata persentase lemak abdominal dipengaruhi oleh berat lemak abdominal, semakin rendah berat lemak abdominalnya semakin rendah pula persentase lemak abdominalnya. Persentase lemak abdominal ayam broiler betina yang tidak diberikan ekstrak jahe merah (P0: 3,06\%) ini sesuai pendapat Soeparno (1999), dimana kandungan lemak abdominal ayam broiler pada umur enam minggu adalah 2,62\% pada ayam jantan dan 3,05\% pada ayam betina. Kandungan lemak abdominal ayam betina relatif lebih tinggi dibandingkan ayam jantan, hal ini disebabkan sifat pertumbuhan ayam jantan lebih cepat dari ayam betina, energi yang ada lebih banyak dipergunakan untuk pertumbuhan. Terangsangnya selaput lendir perut besar dan usus oleh minyak atsiri yang dikeluarkan rimpang jahe, sehingga mengakibatkan lambung menjadi kosong dan ternak akan mengkonsumsi pakan (Setyanto, et al. 2012). Sifat gingerol sebagai antikoagulan yaitu mampu mencegah penggumpalan darah, diperkirakan juga mampu menurunkan kadar kolestrol. Ramuan herbal mengandung zat bioaktif berupa minyak astiri dan kurkumin yang dapat menurunkan lemak abdominal pada broiler. Minyak astiri dan kurkumin yang dapat merangsang dinding kantong empedu dengan menetralkan kondisi asam dari saluran usus dan mengurangi mengemulsian lemak sehingga pembentukan lemak berkurang. Selain itu, adanya minyak astiri dan kurkumin dapat merangsang keluarnya getah pankreas mengeluarkan enzim lipase yang dapat memecah asam lemak gliserol sehingga lemak yang terbentuk berkurang (Afriastini, 2011).

Selain itu penimbunan lemak dipengaruhi oleh beberapa faktor antara lain komposisi ransum, galur, jenis kelamin, umur, dan temperatur lingkungan. (Sudrajad, 1998). Dari faktor komposisi ransum Suhendra (2008) mengemukakan bahwa sumber karbohidrat mudah terpakai, bila diberikan sebagai campuran ransum broiler akan menghasilkan lemak abdominal yang terbanyak serta kadar kolesterol darah yang tinggi. Pendapat yang menyatakan bahwa temperatur lingkungan, galur atau strain, serta umur potong berpengaruh nyata terhadap lemak abdominal juga disampaikan Adiwinarto (2004) dimana suhu pemeliharaan berpengaruh terhadap lemak abdominal, semakin rendah suhu pemeliharaan semakin tinggi penimbunan lemak abdominalnya. Selain itu juga strain berpengaruh terhadap lemak abdominal, karena faktor genetik dapat mempengaruhi penampilan ternak hingga $30 \%$. Faktor umurpun demikian, dimana semakin awal dilakukan pemotongan semakin rendah lemak abdominalnya, hal ini dikarenakan pada 
umur yang mendekati masa pubertas jaringan tubuh dan lemak mulai terbentuk

\section{SIMPULAN DAN SARAN \\ Simpulan}

Penelitian ini diperoleh simpulan bahwa pemberian ekstrak jahe merah dapat menurunkan berat dan persentase lemak abdominal, tetapi tidak mempengaruhi berat dan persentase karkas

\section{Saran}

Ekstrak jahe merah dapat digunakan untuk menurunkan berat dan persentase lemak abdominal, sehingga bagi yang ingin mengkonsumsi ayam broiler dengan kandungan lemak yang lebih rendah, disarankan membeli ayam broiler yang diberi ekstrak jahe.

\section{DAFTAR PUSTAKA}

Abubakar, A. 2003. Mutu Karkas HasilPemotongan Tradisional Penerapan Sistem Hazard Analisis Critikal Control poin. Balai Penelitian Ternak Bogor.

Adiwinarto, G. 2004. Pengaruh Cengkraman Panas Dan Strain Terhadap Laju Pertumbuhan Nisbi Ayam Broiler. STPP Magelang. Magelang.

Afriastini, J. J. 2011. Bertanam Kencur. Penebar Swadaya, Jakarta

Andoko, A dan Hartomo. 2005. Budidaya Daya dan Peluang Bisnis Jahe. AgroMedia Pustaka. Jakarta.

Health. 2007. Khasiat Jahe. Diakses 1 Agustus 2016. http://victorhealth.blogspot.co.id/2007/09/khasi at-jahe.html
Herawati. 2006. Pengaruh Penambahan Fitobiotik Jahe Merah (Zingiber Officinale Rosc) terhadap Produksi dan Profil Darah Ayam Broiler. Jurnal Ilmu Peternakan Vol. 14 No.2 Tahun 2006. Fakultas Peternakan. Universitas Muhammadiyah Purworejo.

Herawati. 2007. Kajian Penampilan Produksi Ayam Broiler yangDiberikan Pakan Tambahan Fitobiotik Jahe Merah. Agritek. Jurnal Ilmu Pertanian_Kehutanan. April. No 3.

Koswara, S. 2007. Jahe, Rimpang Dengan Sejuta Khasiat. Diakses 2 januari 2008.

http://www.ebookpangan.com.

Setyanto, A., U. Atmomarsono, dan R. Muryani. 2012. Pengaruh Penggunaan Tepung Jahe Emprit (Zingiber officinale var Amarum) dalam Ransum terhadap Laju Pakan dan Kecernaan Pakan Ayam Kampung Umur 12 Minggu. Animal Agriculture Journal. 1 (1): 711 720.

Soeparno.1999. Pengolahan Hasil Ternak. Universitas terbuka. Jakarta

Sudrajad.1998. Budidaya Ternak Unggas. Universitas terbuka. Jakarta.

Suhendra. 2008. Lemak Abdomen dan Kolesterol Darah Broiler yang Mendapat Ransum Mengandung Karbohidrat Mudah Terpakai. Diakses 31 Mei 2008. http://ijon line.net/index.

Sunaryo. 2004. Gema Cemani. Sekolah Tinggi Penyluhan pertanian (STPP). Magelang. 
Supranto. J. 2003. Metode Riset Aplikasinya dalam Pemasaran. PT Rineka Cipta, Jakarta Cet. II edisi ketuju Februari 2003.

Zumbrotun, 2012. Jати Sebagai Feed Additive Dan Feed Suplement Untuk Meningkatkan Efisiensi Dan Kesehatan Broiler. http://vedca.siap.web.id/2012/03/14/ jamu-sebagai-feed-additive-danfeed-suplement-untukmeningkatkan-efisiensi-dankesehatan-broiler-oleh-zumrotun-irmp-widyaiswara-pppptk-pertanian/. Diakses pada Tanggal 15 Oktober 2011. 